\title{
PENGARUH PEMANFAATAN MEDIA PEMBELAJARAN BERBASIS EDMODO TERHADAP HASIL BELAJAR SISWA KELAS $X$ SMK NEGERI 1 BOYOLANGU
}

\author{
Anisah Rohmatillah \\ Bety Nur Achadiyah \\ Universitas Negeri Malang \\ anisahrohmatillah@gmail.com
}

\begin{abstract}
The purpose of this research is to determine the effect of accounting learning using the medium Edmodo on the students' learning outcomes. This study is a quasy-experimental study with pretest-posttest control group design. The population in this study is students of class X Accounting of SMKN 1 Boyolangu whichwere divided into 4 classes. The samples used consisted of two classes who had the most similar characteristics, namely the class $\mathrm{X} \mathrm{KU} \mathrm{KU}_{1}$ and $\mathrm{X}$ $\mathrm{KU}_{2}$. The data collection techniques applied were pretest and posttest. The results showed that the learning by using medium-based Edmodo had significant effect on the student's learning outcomes.
\end{abstract}

Keywords: learning media, edmodo, learning outcomes

\begin{abstract}
Abstrak: Tujuan dari penelitian ini adalah mengetahui adanya pengaruh pembelajaran akuntansi menggunakan media Edmodo terhadap hasil belajar siswa. Penelitian ini merupakan penelitian eksperimen semu dengan pretestposttest control group design. Populasi dalam penelitian ini adalah siswa kelas X Akuntansi SMK Negeri 1 Boyolangu yang terbagi menjadi 4 kelas. Sampel yang digunakan terdiri dari dua kelas yang memiliki karakteristik paling mirip, yaitu kelas $\mathrm{X} \mathrm{KU}_{1}$ dan kelas $\mathrm{X} \mathrm{KU}$ 2. Teknik pengumpulan data dalam penelitian ini menggunakan pretest dan posttest. Hasil dari penelitian ini menyatakan bahwa pembelajaran dengan menggunakan media berbasis Edmodo berpengaruh signifikan terhadap hasil belajar siswa.
\end{abstract}

Kata Kunci : media pembelajaran, edmodo, hasil belajar

Seiring dengan perkembangan yang semakin pesat, kebutuhan akan suatu konsep dan mekanisme pendidikan berbasis Teknologi Informasi tidak terelakkan lagi. Kemajuan internet memengaruhi hampir setiap kegiatan operasional di organisasi masyarakat. Fenomena tersebut menyentuh dunia pendidikan dan pelatihan dengan lahirnya E-Learning. Dalam perkembangannya, sistem $E$ - 
Learning ini digunakan oleh sebagian besar institusi pendidikan di Indonesia, salah satunya adalah SMK (Suriadhi, dkk:2014:2).

Mengacu pada teori konstruktivisme yang beranggapan bahwa pengetahuan adalah hasil konstruksi manusia yang dilakukan melalui proses interaksi dengan objek, fenomena, pengalaman, dan lingkungan mereka. Pengetahuan tidak dapat ditransfer begitu saja dari seseorang kepada yang lain tanpa memahami konteksnya. Dalam pemahaman seperti itu, maka pengetahuan harus diinterpretasikan sendiri oleh masing-masing orang. Model pembelajaran ELearning ini memberi keleluasaan bagi peserta didik untuk melakukan penyerapan materi ajar pada waktu yang dianggap paling tepat oleh peserta didik (Darmawan, 2014:51-52).

Kurikulum SMK terdiri atas tiga kelompok mata pelajaran yaitu kelompok mata pelajaran normatif, adaptif dan produktif. Pelajaran akuntansi termasuk kelompok mata pelajaran produktif. Karena kelompok mata pelajaran produktif bersifat melayani permintaan pasar kerja, yang lebih banyak ditentukan oleh dunia usaha/industri atau asosiasi profesi, maka mata pelajaran produktif diajarkan secara spesifik sesuai dengan kebutuhan tiap program keahlian.

Keterlibatan Teknologi Informasi dan Komunikasi (TIK) sangat diperlukan dalam membantu pembelajaran akuntansi, karena selain dunia pendidikan yang tidak bisa terlepas hubungannya dengan teknologi, TIK juga berguna dalam menghadapi dunia kerja. Salah satu jenis E-Learning yang sudah banyak digunakan di dunia pendidikan adalah Edmodo Social Network . Edmodo membantu guru memanfaatkan kekuatan media sosial untuk membangun sebuah kelas virtual berdasarkan pembagian kelas nyata di sekolah, dimana dalam kelas tersebut terdapat penugasan, quiz dan pemberian nilai pada setiap akhir pembelajaran. Pada saat ini mayoritas siswa cenderung menyenangi teknologi dan akrab dengannya. Edmodo adalah sebuah situs yang diperuntukan bagi pendidik untuk membuat kelas virtual. Situs tersebut gratis dan gampang digunakan selama seorang guru dan murid bisa terhubung dengan internet.

Perbedaan dan pengembangan penelitian ini jika dibandingkan dengan penelitian terdahulu terletak pada pemilihan konten Edmodo. Pada penelitian terdahulu fitur edmodo yang dimanfaatkan hanya sebatas penyampaian materi dan penugasan. Untuk penelitian ini fitur Edmodo yang digunakan semakin bertambah, yaitu materi akuntansi, soal-soal latihan, studi kasus, kuis online (Quiz),dan artikel terkait (File and Links), sehingga dapat digunakan sebagai sumber belajar bagi siswa. Perbedaan selanjutnya terletak pada lokasi sampel dan populasi penelitian, mata pelajaran dan materi pelajaran yang diteliti juga berbeda dari penelitian sebelumnya.

Hasil observasi yang dilakukan peneliti di SMK Negeri 1 Boyolangu mengindikasikan media pembelajaran yang digunakan di sekolah tersebut masih konvensional dan belum menggunakan media pembelajaran e-learning khususnya untuk mata pelajaran akuntansi. Penggunaan media yang bersifat konvensional, yaitu dengan metode ceramah, hafalan,dan tanya jawab tanpa memberikan variasi media lain sebagai alternatif lain dapat memicu kebosanan dan menurunkan minat siswa dalam belajar sehingga akan menimbulkan keterpaksaan dalam belajar. 
Penggunaan metode pembelajaran yang masih konvensional ini, dapat dijadikan sebagai bukti bahwa belum dimaksimalkannya sarana prasarana yang ada di sekolah, seperti sinyal wi-fi yang stabil. Ditunjang dengan banyaknya siswa yang sudah memiliki laptop dan perangkat gadget yang dapat digunakan untuk mengakses berbagai macam hal.

Penelitian ini akan mengkonfirmasi teori konstruktivisme yang menyatakan bahwa belajar bukan hanya sekadar menghafal, akan tetapi proses mengkonstruksi pengetahuan melalui pengalaman. Pengetahuan bukanlah hasil "pemberian" dari orang lain seperti guru, akan tetapi hasil dari proses mengkonstruksi yang dilakukan setiap individu. Pengetahuan hasil dari "pemberian" tidak akan bermakna. Adapun pengetahuan yang diperoleh melalui proses mengkonstruksi akan memberikan makna mendalam atau lebih dikuasai dan lebih lama tersimpan/diingat dalam setiap individu.

Penelitian ini dilakukan untuk membuktikan adanya keterkaitan antara hasil belajar siswa dengan pembelajaran yang melibatkan siswa untuk berinteraksi secara aktif, salah satu caranya dengan memberi stimulus dari luar melalui media pembelajaran Edmodo yang bertujuan mempermudah belajar para siswa. Guru dan siswa diharapkan dapat proaktif dalam memanfaatkan teknologi informasi untuk mendukung kegiatan pembelajaran agar hasilnya berdampak positif terhadap hasil belajar siswa.

\section{METODE}

Penelitian ini merupakan penelitian eksperimen semu (quasy experiment research) yaitu suatu penelitian yang dilakukan berdasarkan suatu percobaan pura-pura dimana kelompok kontrol tidak dapat berfungsi sepenuhnya mengontrol variabel-variabel luar yang mempengaruhi pelaksanaan eksperimen yang sebenarnya (Sugiyono, 2012:114). Tujuan penelitian ini adalah untuk memperoleh gambaran yang jelas mengenai seberapa besar pengaruh variabel bebas, yakni media pembelajaran berbasis Edmodo terhadap variabel terikat, yakni hasil belajar siswa.

Rancangan penelitian ini menggunakan Pre Test-Post Test Control Group Design. Penelitian ini membagi sasaran penelitian menjadi dua kelompok sampel yaitu kelompok eksperimen dan kelompok kontrol. Kelompok eksperimen berfungsi sebagai kelompok percobaan yang mendapat perlakuan dari media pembelajaran berbasis Edmodo, sedangkan kelompok kontrol berfungsi sebagai kelompok pembanding yang digunakan untuk mengukur perbedaan hasil belajar kelompok eksperimen. Kelompok kontrol adalah kelompok yang kegiatan pembelajarannya menggunakan metode konvensional yaitu ceramah dan Tanya jawab di kelas.

Populasi dalam penelitian ini adalah siswa kelas X Akuntansi SMK Negeri 1 Boyolangu yang terbagi menjadi 4 kelas yang berjumlah 152 siswa. Sampel diambil menggunakan teknik purposive sample yaitu teknik pengambilan sampel yang ditentukan berdasarkan tujuan tertentu (Trianto, 2011:261). Sampel 
yang diterapkan terdiri dari dua kelas yang memiliki karakteristik paling mirip,

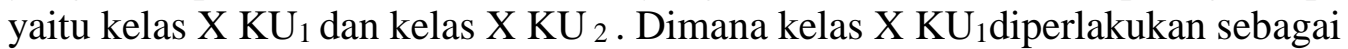
kelas kontrol dan kelas $\mathrm{X} \mathrm{KU} \mathrm{KU}_{2}$ sebagai kelas eksperimen. Dikatakan memiliki karakteristik paling mirip dikarenakan menurut guru bidang studi yang bersangkutan masing-masing kelas tersebut dapat diasumsikan mewakili populasi. Kesamaan karakteristik sampel yang dimaksud diantaranya adalah umur siswa (dari jenjang pendidikan yang sama, yakni kelas X), latar belakang jurusan (akuntansi), dan menurut guru bidang studi bersangkutan, kedua kelas tersebut memiliki kecenderungan tingkat prestasi yang relatif sama dibandingkan dengan kelas lainnya.

Intrumen penelitian ini menggunakan instrumen tes, yaitu tes hasil belajar yang digunakan untuk mengetahui hasil belajar melalui pembelajaran akuntansi yang berbasis Edmodo pada siswa kelas X SMK Negeri 1 Boyolangu. Bentuk tes hasil belajar adalah tes tulis yang diambil dari materi yang diajarkan.Sedangkan tes hasil belajar dibagi menjadi dua yaitu pre test dan post test, yang terdiri dari 20 soal objektif. Uji coba yang digunakan pada instrumen tes yang akan digunakan meliputi tingkat kesukaran item soal, daya pembeda, kesesuaian dengan kisi-kisi dan RPP.

Data yang digunakan merupakan data kuantitatif yang merupakan data primer, yaitu hasil dari pretest - posttest siswa. Teknik analisis data yang digunakan adalah Uji Normalitas, Uji Homogenitas, dan Uji Hipotesis.

\section{HASIL DAN PEMBAHASAN}

Data hasil belajar dalam penelitian ini diperoleh melalui nilai pretest dan posttest yang dilakukan sebelum dan sesudah siswa diberi perlakuan pembelajaran. Soal pretest dan posttest masing-masing terdiri dari 20 butir soal yang diambil dari materi yang diajarkan yaitu menyusun laporan keuangan perusahaan jasa. Setiap butir soal memiliki nilai 5 untuk jawaban benar dan 0 untuk jawaban salah, sehingga nilai tertinggi pada soal pretest dan posttest ini adalah 100 (20soal x 5).

Data nilai pretest dan posttest kemudian dinyatakan dalam bentuk batas interval dengan tujuan untuk mengetahui sebaran sampel berdasarkan nilai yang telah diperoleh. Panjang kelas interval ditentukan berdasarkan jenjang penilaian instrumen, yaitu 5, sehingga dapat ditentukan panjang intervalnya $20((100-0) / 5)$.

\section{Data Kemampuan Awal Siswa (Pretest)}

Data kemampuan awal siswa diperoleh dari hasil pretest yang dilakukan sebelum kelas eksperimen dan kelas kontrol diberikan perlakuan pembelajaran. Pada kelas eksperimen maupun kelas kontrol siswa yang mengikuti pretest dan posttest berjumlah 35 siswa.

Dari penghitungan dapat diketahui bahwa 34\% siswa dari kelas kontrol memiliki kemampuan awal dengan kategori baik, $60 \%$ siswa tergolong memiliki kemampuan awal cukup baik, dan $6 \%$ siswa memiliki kemampuan awal kurang baik. Sedangkan untuk kelas eksperimen, $34 \%$ siswa memiliki kemampuan awal 
baik, $60 \%$ siswa memiliki kemampuan awal cukup baik, dan $6 \%$ memiliki kemampuan awal kurang baik.

Nilai tertinggi dan terendah untuk kelas kontrol adalah 80 dan 10, sedangkan untuk kelas eksperimen adalah 75 dan 40. Rata-rata data kemampuan awal siswa untuk kelas kontrol sebesar 57,57 dan untuk kelas eksperimen sebesar 58,14 .

\section{Data Kemampuan Akhir Siswa (Posttest)}

Data kemampuan akhir siswa ini diperoleh dari hasil posttest yang dilakukan setelah kedua kelompok diberikan perlakuan. Jumlah siswa dan jumlah butir soal yang diberikan sama dengan pada saat pemberian pretest pada masingmasing kelas yaitu 35 siswa dan 20 butir soal.

Dari penghitungan distribusi frekuensi dapat diketahui bahwa 37\% siswa dari kelas kontrol memiliki kemampuan akhir dengan kategori sangat baik, 54\% siswa tergolong memiliki kemampuan akhir baik, dan $9 \%$ siswa memiliki kemampuan akhir cukup baik. Sedangkan untuk kelas eksperimen, 69\% siswa memiliki kemampuan akhir baik dan $31 \%$ siswa memiliki kemampuan akhir baik.

Nilai tertingi dan terendah untuk kelas kontrol adalah 95 dan 55, sedangkan untuk kelas eksperimen adalah 95 dan 65. Rata-rata data kemampuan akhir siswa untuk kelas kontrol sebesar 78,71 dan untuk kelas eksperimen sebesar 85,29 . Berdasarkan data tersebut dapat dikatakan bahwa nilai rata-rata data kemampuan akhir siswa kelas eksperimen lebih tinggi dibandingkan dengan kelas kontrol.

\section{Analisis Data}

Sebelum dilakukan uji hipotesis, data perlu diuji terlebih dahulu untuk memenuhi prasyarat uji hipotesis. Uji prasyarat analisis dalam penelitian ini menggunakan uji normalitas dan uji homogenitas

\section{Uji Normalitas}

Dalam penelitian ini pengujian normalitas nilai posttest dilakukan dengan menggunakan teknik Kolmogorov-Smirnov menggunakan bantuan komputer progam SPSS16 for Windows. Hasil uji normalitas nilai posttest kelas eksperimen dan kelas kontrol dapat dilihat pada tabel berikut:

Tabel Hasil Uji Normalitas Data Kemampuan Akhir Siswa (Posttest)

\begin{tabular}{lcc}
\hline \multicolumn{1}{c}{ Vaniabel } & Kelas Kontrol & Kelas Eksperimen \\
\hline $\mathbf{N}$ & 35 & 35 \\
Kolmogorov-Smirnov & 0,905 & 1,024 \\
Asymp.sig & 0,386 & 0,245 \\
Kesimpulan & Normal & Normal \\
\hline
\end{tabular}

(Sumber: Uji Normalitas dengan bantuan progam SPSS16 for Windows)

Nilai signifikansi untuk kelas kontrol adalah 0,386 > 0,05 dan untuk kelas eksperimen menunjukkan nilai signifikansi 0,245 >0,05. Hal ini dapat disimpulkan bahwa nilai posttest adalah berdistribusi normal. Karena data posttest 
berdistribusi secara normal, sehingga analisis data berikutnya menggunakan statistik parametrik $t$-test.

\section{Uji Homogenitas}

Uji homogenitas digunakan untuk mengetahui apakah nilai postest homogen atau tidak. Uji homogenitas ini menggunakan uji kesamaan dua varian dengan uji Levenne. Data uji homogenitas selengkapnya dapat dilihat pada Lampiran. Hasil uji homogenitas kelas eksperimen dan kelas kontrol dapat dilihat pada tabel berikut:

Tabel Hasil Uji Homogenitas Data Kemampuan Akhir Siswa (Posttest)

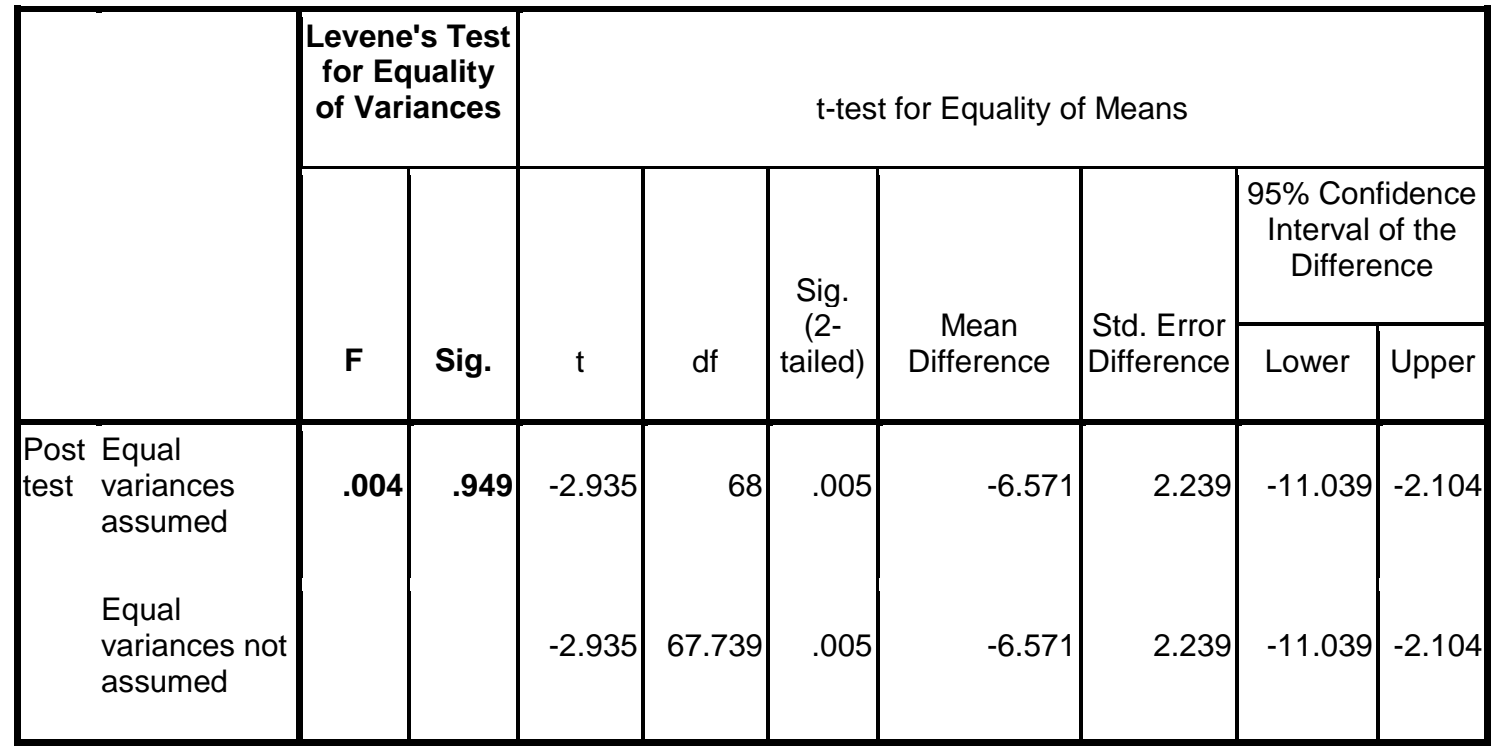

(Sumber: Uji homogenitas dengan bantuan progam SPSS16 for Windows)

Dari tabel 4.6 dapat diketahui bahwa nilai signifikansi pada hasil belajar siswa adalah sebesar 0,949 . Nilai ini lebih besar dari taraf signifikansi sebesar 0,05 . Karena $0,949>0,05$ maka dapat dikatakan tidak ada perbedaan varian pada data nilai hasil belajar siswa kelas kontrol dan kelas eksperimen (data homogen). Berdasarkan hasil uji Levene ini, pengujian dilanjutkan menggunakan uji t dengan menggunakan equal variance assumed (diasumsikan kedua varian sama). Namun apabila data yang diperoleh $<0,05$ maka dikatakan data tidak homogen, sehingga menggunakan equal variances not assumed.

\section{Uji Hipotesis}

Pengujian hipotesis dilakukan dengan menggunakan Uji t, karena data posttest berdistribusi normal dan varian datanya homogen. Uji t disini untuk mengetahui apakah ada perbedaan antara hasil belajar siswa pada kelas eksperimen yang diajar menerapkan media pembelajaran berbasis Edmodo dengan kelas kontrol yang tidak menerapkan media pembelajaran berbasis Edmodo. Apabila dari hasil uji tersebut menunjukkan nilai signifikansi < 0,05 maka dapat disimpulkan terdapat perbedaan hasil belajar antara kelas kontrol dengan kelas eksperimen. Data uji t selengkapnya dapat dilihat pada Lampiran. Hasil uji t tersebut dapat ditunjukkan dalam tabel berikut: 
Tabel Hasil t-test Data kemampuan akhir Siswa (Posttest)

\begin{tabular}{lc}
\hline \multicolumn{1}{c}{ Parameter } & t-test for equality of means \\
\cline { 2 - 2 } & Sig. (2-tailed) \\
\hline Nilai posttest & 0,005 \\
\hline (Sumber: Uji t dengan bantuan komputer
\end{tabular}

(Sumber: Uji t dengan bantuan komputer progam SPSS16 for Windows)

Dari tabel 4.7 dapat diketahui bahwa terdapat perbedaan antara hasil belajar siswa pada kelas eksperimen yang diajar menggunakan media pembelajaran berbasis Edmodo dengan kelas kontrol tidak menggunakan media pembelajaran berbasis Edmodo. Hal ini ditunjukkan dengan adanya angka signifikansi sebesar 0,005 $<0,05$. Hal ini mengindikasikan bahwa hipotesis dimana ada perbedaan hasil belajar siswa kelas eksperimen yang menerapkan media pembelajaran berbasis Edmodo pada mata pelajaran akuntansi dengan siswa kelas kontrol yang tidak menerapkan media pembelajaran berbasis Edmodo diterima.

Berdasarkan analisis statistik, diperoleh hasil yang menunjukkan bahwa terdapat perbedaan hasil belajar siswa antara kelas yang diajar dengan menggunakan media berbasis Edmodo (kelas eksperimen) dengan kelas yang diajar tanpa menggunakan media berbasis Edmodo (kelas kontrol). Hasil belajar kelas eksperimen yang diajar dengan menggunakan media berbasis Edmodo dan kelas kontrol yang diajar tanpa mengunakan media berbasis Edmodo dalam penelitian ini sama-sama mengalami peningkatan, namun peningkatan hasil belajar tersebut lebih tinggi di kelas yang menggunakan media berbasis Edmodo. Hal ini ditunjukkan dengan rata-rata data kemampuan akhir kedua kelas, dimana rata-rata kelas eksperimen lebih tinggi daripada rata-rata kelas kontrol.

Dari hasil uji analisis $t$-test pada penelitian ini sejalan dengan pendapat Budiningsih (2012:58) tentang pandangan konstruktivistik yang menyatakan bahwa belajar merupakan suatu proses pembentukan pengetahuan. Pembentukan tersebut harus dilakukan oleh si belajar (siswa). Siswa harus aktif melakukan kegiatan, aktif berpikir, menyusun konsep dan memberi makna menurut pemahamanya sendiri tentang hal-hal yang sedang dipelajari. Proses belajar yang bermakna akan terbentuk apabila guru tidak hanya memberikan pengetahuan kepada siswa melainkan juga memberikan kesempatan pada siswa untuk membangun pengetahuannya sendiri melalui proses menemukan dan menerapkan konsep yang sudah siswa pahami sendiri. Media pembelajaran berbasis Edmodo disediakan untuk membantu pembentukan pengetahuan yang dilakukan siswa. Penggunaan media Edmodo ini efektif dikarenakan Edmodo memiliki beberapa ke unggulan yaitu: (1) Mengadaptasi tampilan seperti facebook secara sederhana, sehingga membuat siswa lebih termotivasi untuk belajar, (2) Edmodo mendukung preview berbagai jenis format file, dan (3) Edmodo tidak hanya dapat diakses dengan menggunakan PC (laptop / desktop) tetapi juga bisa diakses dengan menggunakan gadget berbasis Android atau $i O S$.

Pemanfaatan media pembelajaran berbasis Edmodo ini menunjang proses pembelajaran yang menyenangkan dan menarik bagi siswa serta memperkuat motivasi dan semangat serta perhatian siswa untuk belajar, sehingga gangguan dalam kelas dapat diminimalisir. Situasi tersebut sangat jelas terlihat dari sikap siswa kelas eksperimen yang cukup baik, siswa terlihat tertarik mengikuti 
pelajaran dengan fokus pada media Edmodo yang di dalamnya terdapat materi mengenai Pelaporan Keuangan. Keadaan ini membuktikan bahwa pemanfaatan media berbasis Edmodo dapat meningkatkan minat dan motivasi belajar yang pada akhirnya akan meningkatkan hasil belajar.

Penerapan media pembelajaran berbasis Edmodo ini mampu membawa perubahan dalam kegiatan belajar mengajar. Proses kegiatan belajar dan mengajar yang semula hanya berpusat pada guru, berubah menjadi proses kegiatan belajar mengajar yang berpusat pada siswa, dimana guru berperan sebagai fasilitator, inspirator, dan motivator. Proses tersebut secara tidak langsung akan menghasilkan suatu pembelajaran yang lebih efektif.

Pembelajaran akuntansi yang selama ini diterapakan dengan menggunakan pembelajaran konvensional membuat siswa kurang menguasai materi secara keseluruhan. Sehingga model pembelajaran berbasis proyek ini dapat dijadikan alternatif membuat siswa lebih aktif dan mampu memahami suatu pengetahuan secara utuh.

Hasil yang didapat pada penelitian ini juga mendukung penelitian serupa yang pernah dilakukan oleh peneliti sebelumnya. Salah satunya adalah penelitian milik Suriadhi dkk (2014) yang menyebutkan terdapat perbedaan yang signifikan hasil belajar siswa antara sebelum dan sesudah menggunakan $e$ Learning berbasis Edmodo. Pada penelitian ini dibuktikan bahwa kualitas $e$ learning berbasis Edmodo menunjukkan kualifikasi sangat baik, sehingga penggunaan e-learning berbasis Edmodo efektif untuk meningkatkan hasil belajar siswa. Pemahaman kosep dan kemampuan berpikir kritis siswa kelas eksperimen lebih baik daripada kelas kontrol, hal ini dapat dilihat dari perolehan hasil belajar siswa yang memiliki perbedaan setelah diterapkan perlakuan pembelajaran yang berbeda.

Dalam konteks penelitian ini, kondisi sikap siswa seperti yang terlihat, siswa tertarik pada media pembelajaran berbasis Edmodo ini. Hal itu tercermin saat guru menjelaskan langkah-langkah menggunakan media pembelajaran berbasis Edmodo sebelum kegiatan pembelajaran berlangsung. Kemudian guru meminta masing-masing siswa untuk membuka akun baru Edmodo. Siswa diminta untuk mempelajari materi-materi yang terdapat di dalam Edmodo tersebut, hal itu dimaksudkan agar siswa bekerja secara aktif dan bebas menciptakan konsep untuk memahami materi. Penggunaan media berbasis Edmodo ini akan memudahkan siswa dalam memahami materi pembelajaran. Hal itu terlihat dari sikap siswa kelas eksperimen yang terlihat antusias dalam menjelajahi akun Edmodo masingmasing. Siswa aktif mencoba satu per satu fitur yang terdapat di dalam Edmodo. Tidak hanya mempelajari materi, siswa juga saling berinteraksi satu sama lain melalui pesan dinding hingga mengerjakan kuis. Siswa juga aktif bertanya dan menemukan kesulitan-kesulitan yang dihadapi saat proses belajar. Dan pertanyaan tersebut siswa kemukakan di pesan dinding sehingga guru dapat memberikan langsung penjelasan yang kemudian dapat diperhatikan juga oleh siswa yang lain. Hal ini berarti siswa mulai belajar untuk berfikir kritis terhadap materi yang diberikan. Dengan demikian, kondisi siswa kelas eksperimen seperti ini membuktikan bahwa penggunaan media berbasis Edmodo dapat meningkatkan 
minat, perhatian, dan motivasi siswa yang pada akhirnya nanti akan berdampak tidak langsung terhadap peningkatan hasil belajar siswa.

Dari hasil penelitian yang didukung oleh pendapat ahli dan beberapa penelitian terdahulu tampak bahwa pentingnya media pembelajaran dalam kegiatan belajar karena siswa akan memunculkan sikap yang baik untuk mau belajar, dan juga siswa belajar karena ada tujuan-tujuan yang hendak dicapai oleh siswa tersebut yang salah satunya adalah hasil belajar, sesuai dengan hasil penelitian yang menunjukkan nilai kemampuan akhir siswa kelas eksperimen lebih tinggi daripada kelas kontrol yang mengindikasikan bahwa tujuan dari pembelajarn tercapai. Berdasarkan nilai kemampuan akhir siswa tersebut dapat dijelaskan bahwa pembelajaran menggunakan media pembelajaran berbasis Edmodo berpengaruh terhadap hasil belajar siswa kelas X SMK Negeri 1 Boyolangu.

Dari keseluruhan pembahasan di atas implikasi yang harus dilakukan oleh sekolah adalah lebih memperhatikan segala sesuatu yang dapat memengaruhi proses belajar hingga hasil belajar yang akan diraih siswa, yang salah satunya adalah menciptakan inovasi-inovasi media pembelajaran yang dapat meningkatkan minat dan perhatian siswa, sehingga siswa mendapatkan pengetahuan yang luas dan kuat untuk menyesuaikan diri atau beradaptasi dengan perubahan yang terjadi terutama di lingkungan kerja karena memang siswa-siswi SMK dipersiapkan untuk terjun ke dunia kerja.

\section{SIMPULAN DAN SARAN}

\section{Simpulan}

Penelitian yang dilakukan pada siswa kelas X SMKN 1 Boyolangu memberikan kesimpulan bahwa terdapat perbedaan hasil belajar antara pembelajaran menggunakan media berbasis Edmodo dengan pembelajaran konvensional pada siswa dimana penggunaan media ini dapat meningkatkan hasil belajar siswa pada mata pelajaran pengantar akuntansi materi pelaporan keuangan. Hal ini dikarenakan media pembelajaran ini melibatkan siswa secara aktif dalam membangun pengetahuannya sendiri, sehingga siswa mampu memahami apa yang dipelajarinya secara utuh. Sedangkan pada pembelajaran konvensional, siswa tidak berpartisipasi secara aktif dalam proses perolehan pengetahuan karena siswa hanya diposisikan sebagai penerima informasi dan guru memposisikan diri sebagai pusat dalam kegiatan belajar mengajar.

Pemanfaatan media berbasis Edmodo ini memperoleh respon dan ditanggapi dengan antusias oleh siswa sehingga mampu meningkatkan keterampilan siswa. Siswa termotivasi untuk mengikuti pelajaran terbukti dari situasi dalam kelas yang aktif dan menyenangkan. Oleh karena itu, siswa kelas eksperimen mampu mendapat hasil belajar yang baik bila dibandingkan dengan kelas kontrol. Implikasi dari hasil penelitian ini adalah apa yang diargumentasikan oleh Hamalik (dalam Arsyad, 2011: 15) yang mengemukakan bahwa pemakaian media pembelajaran dalam proses belajar mengajar dapat meningkatkan keinginan dan minat yang baru, membangkitkan motivasi dan rangsangan kegiatan belajar 
dan bahkan membaca pengaruh-pengaruh psikologis terhadap siswa yang pada akhirnya dapat meningkatkan hasil belajar adalah berlaku dalam pembelajaran akuntansi.

\section{Saran}

Bagi guru akuntansi disarankan dalam proses pembelajaran sebaiknya guru menggunakan media pembelajaran seperti media berbasis Edmodo ini agar kegiatan belajar mengajar menjadi lebih menarik dan tidak membosankan.

Bagi Penelitian selanjutnya hendaknya menggunakan sampel yang berbeda dan lebih luas untuk menguji kembali keberlakuan teori mengenai media pembelajaran berbasis Edmodo. Dan karena dalam penelitian ini materi yang dieksperimenkan sebatas pelaporan keuangan, sehingga pada penelitian selanjutnya sebaiknya dapat mengambil materi sebagai bahan eksperimen penelitian.

\section{DAFTAR RUJUKAN}

Arsyad, A.2011. Media Pembelajaran. Jakarta : Raja Grafindo Persada.

Budiningsih, C.Asri. 2012. Belajar dan Pembelajaran. Jakarta:Rineka Cipta

Darmawan, Deni. 2014. Pengembangan E-Learning Teori dan Desain. Bandung:Remaja Rosdakarya.

Sugiyono. 2005. Metode Penelitian Pendidikan Pendekatan Kuantitatif, Kualitatif dan $R \& D$. Bandung: Alfabeta.

Suriadhi, Gede, I Dewa Kade Tastra \& Ign. Wayan Suwatra. Pengembangan ELearning Berbasis Edmodo Pada Mata Pelajaran IPA Kelas VIII di SMP Negeri 2 Singaraja. Journal Edutech Universitas Pendidikan Ganesha, 2 (1). (Online), (http://ejournal.undiksha.ac.id/index.php/JJTP/article/viewFile/3795/3041) , diakses 10 September 2014.

Trianto. 2011. Pengantar Penelitian Pendidikan bagi Pengembangan Profesi

Pendidikan dan Tenaga Kependidikan. Jakarta:Kencana. 